\title{
Implementation of the Ottawa ankle rules by general practitioners in the emergency department of a Turkish district hospital
}

\author{
Murat Daş, M.D., ${ }^{1}$ Aytun Temiz, M.D., ${ }^{2}$ Yunsur Çevik, M.D. ${ }^{3}$ \\ 1'Department of Emergency Medicine, Balıkesir Edremit State Hospital, Balıkesir-Turkey \\ ${ }^{2}$ Department of Orthopaedics and Traumatology, Edremit State Hospital, Balıkesir-Turkey \\ ${ }^{3}$ Department of Emergency Medicine, Ankara Keçiören Training Hospital, Ankara-Turkey
}

\begin{abstract}
BACKGROUND: The present objective was to assess implementation of the Ottawa ankle rules (OAR) as a method of fracture prediction in the emergency department (ED) of a Turkish state hospital.

METHODS: Patients who presented to the ED of our hospital with acute ankle injury were evaluated. All were examined by a general practitioner, after which a series of ankle and foot x-rays (anteroposterior and lateral) were performed. Radiography was examined by a radiologist and an orthopedic surgeon, both of whom were blinded to OAR results. Radiographic results were compared to results of OAR implementation. Sensitivity and specificity of the OAR in the diagnosis of fracture was calculated.
\end{abstract}

RESULTS: A total of $25 \mathrm{I}$ (6I.97\%) patients were diagnosed as positive (+) for fracture after OAR implementation, I54 (38.02\%) as negative $(-)$. Clinically significant fracture was detected in $62(15.3 \%)$ patients. A total of 61 (98.4\%) patients with significant fracture were OAR (+); I (I.6\%) was OAR (-). However, 190 (55.4\%) patients without fracture were OAR (+); I53 (44.6\%) were OAR (-) $(\mathrm{p}<0.00 \mathrm{I})$. Sensitivity, specificity, and positive and negative predictive values of OAR implementation in the prediction of fracture were 98.39\%, 44.61\%, 24.30\%, and 99.35\%, respectively. Area under the curve (AUC) was 0.71 . According to these results, it was determined that use of radiography could be reduced by $38.02 \%$ if the OAR were implemented.

CONCLUSION: The OAR are a highly sensitive means of screening of patients with acute ankle and mid-foot injuries. Application of the OAR by well-trained general practitioners can lead to significant reduction in the number of $x$-rays performed, thereby reducing cost of treatment and radiation exposure, in addition to saving time for patients and staff.

Keywords: General practitioners; Ottawa ankle rules.

\section{INTRODUCTION}

Ankle and foot injuries are common clinical conditions, accounting for 6-12\% of emergency department (ED) cases. [1,2] The majority of these patients undergo plain radiography to rule out fracture, while clinically significant fractures account for only $15 \%$ of the injuries. ${ }^{[3]}$ This figure suggests that

\footnotetext{
Address for correspondence: Aytun Temiz, M.D.

Hasan Basri Çantay Mah., Tank Çiftliği Yolu Sokak, Altinkent Sitesi, E Blok, Daire 8, Balıkesir, Turkey

Tel: +90 266 - 373 I3 13 E-mail: aytuntemiz@hotmail.com

Qucik Response Code Ulus Travma Acil Cerrahi Derg

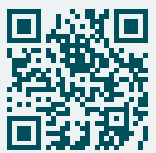

2016;22(4):36I-364

doi: $10.5505 /$ tjtes.2016.72662

Copyright 2016

TJTES
}

a significant number of patients are unnecessarily subjected to x-ray exposure. ${ }^{[4]}$ In an effort to reduce ED wait time and unnecessary radiography, Stiell et al. ${ }^{[5]}$ from the University of Ottawa and the Ontario Ministry of Health developed a set of clinical guidelines known as the Ottawa ankle rules (OAR). The aim of OAR implementation is to exclude diagnosis of ankle and mid-foot fracture on the basis of a thorough physical examination.

The OAR have been widely applied in many countries, ${ }^{[6-1]}$ and are regarded as a highly sensitive and modestly specific method of detecting fracture in clinical setting. ${ }^{[2]}$ However, the introduction of any new diagnostic method in a specific clinical setting and culture requires considerable caution, as sensitivity and specificity may be significantly affected. ${ }^{[1]}$ In Turkey, a patient with musculoskeletal injury is typically first examined by a general practitioner at a local state hospital. For this reason, the present aim was to assess the efficacy of the OAR as a method of fracture prediction in the ED 
of a Turkish state hospital. It was hypothesized that the implementation of the OAR by general practitioners in an ED would significantly reduce the number of unnecessary $x$-rays, without increasing the number of missed fractures.

\section{MATERIALS AND METHODS}

The present study was approved by the ethics committee of the Balikesir University Faculty of Medicine. It was a retrospective case-control analysis of prospectively planned and collected data. Consecutive patients who presented to the ED of our hospital with acute ankle injury between October 2014 and February 2015 were evaluated. Exclusion criteria were injuries that had occurred longer than 10 days prior, patient age younger than 18 years, those who were intoxicated or unconscious, as well as those with previously symptomatic ankle, insensate leg, open fractures, evidence of neurovascular compromise, or obvious ankle or foot deformities. All included patients were examined by a general practitioner in the ED. Examining practitioners attended a presentation regarding the use and implementation of the OAR, and received a printed card with a description (Fig. I). In addition, descriptive posters of the OAR were hung in the ED. According to the OAR, clinically significant fracture should be suspected when bone tenderness is present along the distal 6 centimeters of the posterior, medial, or lateral malleolus, at the base of the $5^{\text {th }}$ metatarsal and navicular bone, or when the patient is unable to bear weight, both in the immediate aftermath of the event and in the ED. Following OAR assessment, participants underwent a series of ankle and foot $\mathrm{x}$-rays (anteroposterior and lateral).

Radiography was interpreted by a radiologist and an orthopedic surgeon blinded to the OAR status of each patient. Any avulsed fracture fragment longer than $3 \mathrm{~mm}$ was considered clinically significant. If fracture fragment was shorter than 3 $\mathrm{mm}$, the radiograph was interpreted as a clinically insignificant, and a result of "no fracture" was reported in analysis. Radiographic results were compared to the findings of OAR implementation in order to calculate OAR sensitivity and specificity in the diagnosis of fracture. Negative and positive predictive values, as well as area under the curve (AUC) were calculated.

Statistical analysis was performed using SPSS software (version 22.0; SPSS Inc., Chicago, IL, USA). Patients with ankle sprain account for approximately $6 \%$ of all those presenting to the $E D,{ }^{[1,2]}$ a piece of information used for the present power analysis. With significance level of $\alpha=0.05$ and margin of error of $d=0.02$, sample size was determined as $n=405$. Normalcy of distribution was checked using Shapiro-Wilk test. Descriptive statistics were expressed as median (minimum-maximum) for continuous variables with abnormal distribution, and as frequency, percentage for categorical variables. McNemar's test was used to analyze categorical data of dependent variables.

\section{RESULTS}

A total of 405 patients were presently included. Mean age was 37.46 (I8-85) years, 248 (6I.2\%) patients were men, and I 57 (38.8\%) were women. The OAR positive (+) population included $25 \mathrm{I}$ (6I.97\%) patients, while the negative $(-)$ population included 154 (38.02\%) patients. Clinically significant fracture was detected in 62 (I5.3\%) patients. Lateral malleolus fracture was diagnosed in $23(5.67 \%)$ patients, metatarsal fracture in $23(5.67 \%)$, medial malleolus fracture in 4 (0.98\%), navicular bone fracture in $4(0.98 \%)$, first metatarsal fracture in $3(0.74 \%)$, calcaneal fracture in $2(0.49 \%)$, talus lateral process fracture in $2(0.49 \%)$, and both medial and posterior malleolar fracture was diagnosed in I $(0.24 \%)$ patient. No fracture was found in $343(84.69 \%)$ patients.

A total of 61 (98.4\%) patients with significant fracture were OAR (+), and I (I.6\%) was OAR (-). However, I 90 (55.4\%) patients without fracture were OAR $(+)$, and I53 $(44.6 \%)$ were OAR $(-)(p<0.001$; Fig. 2). Sensitivity, specificity, and positive and negative predictive values of OAR implementation in the prediction of fracture were $98.39 \%, 44.61 \%$, $24.30 \%$, and $99.35 \%$, respectively (Table I). AUC was 0.7 I.

According to the present findings, a possible reduction in incidence of unnecessary radiography of $38.02 \%$ was determined. One case of first metatarsal fracture (1.6\%) would have been missed if the decision to perform $x$-ray had been based solely on OAR result.

\section{DISCUSSION}

The present results regarding implementation of the OAR in a Turkish ED were similar to those produced in other settings. Bachmann et al. ${ }^{[3]}$ demonstrated that OAR sensitivity ranged from $96.4-99.6 \%$, and specificity from $26.3-47.9 \%$. Sensitivity represents the number of patients with the condition and

Table I. Performance of the OAR in evaluation of ankle and foot injuries

\begin{tabular}{lccr}
\hline & Fracture (+) $\mathbf{n}(\%)$ & Fracture (-) $\mathbf{n ~ ( \% ) ~}$ & \\
\hline Ottawa (+) & $61(98.4)$ & $190(55.4)$ & Positive predictive value 24.30\% \\
Ottawa (-) & I (1.6) & $153(44.6)$ & Negative predictive value 99.35\% \\
& Sensitivity $98.39 \%$ & Specificity 44.61\% & \\
\hline
\end{tabular}




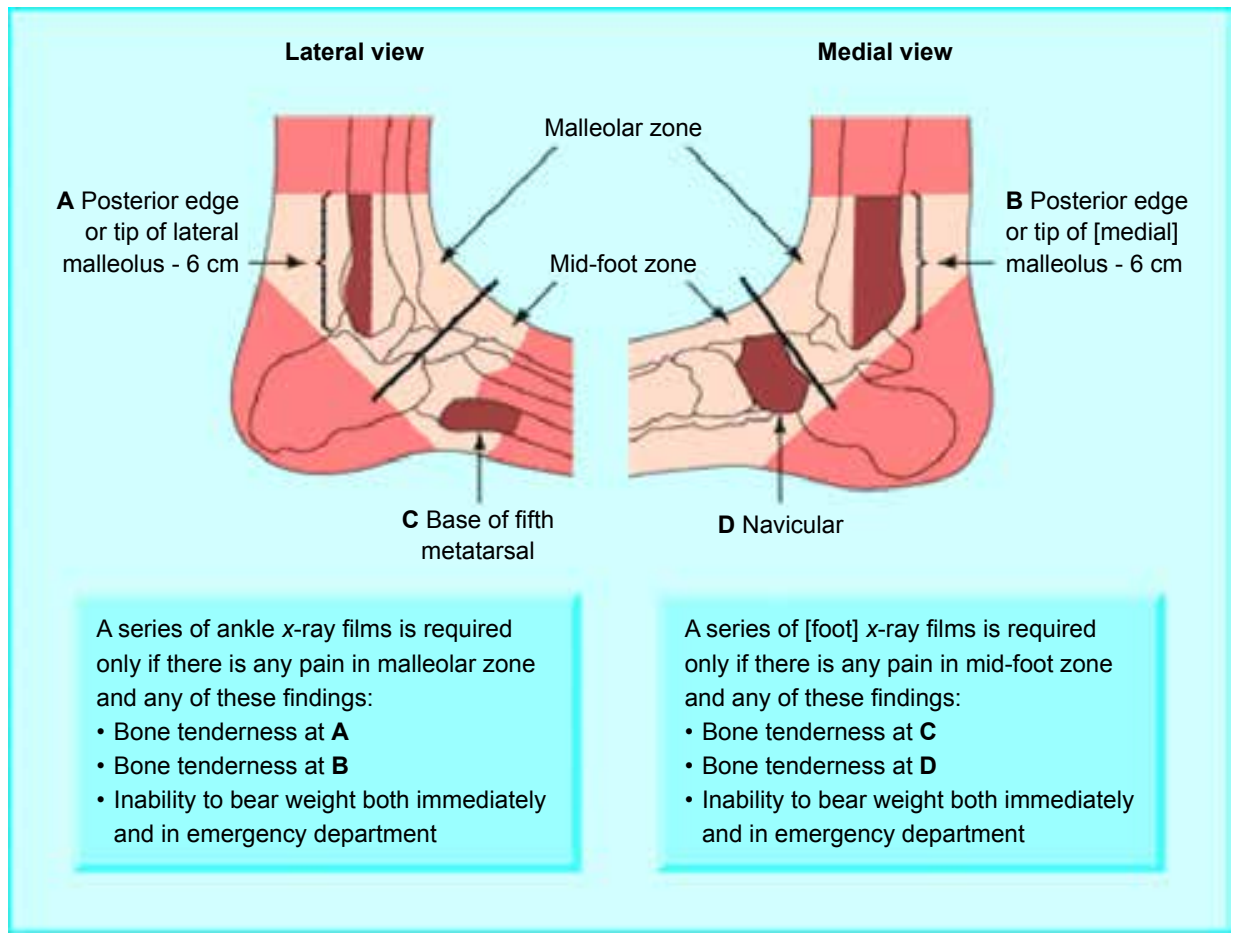

Figure 1. Description of Ottawa ankle rules.

with a positive test. ${ }^{[14]}$ For this reason, an OAR (-) finding is a reasonable indication that no fracture is present. Specificity represents the number of patients without the condition and with a negative test. ${ }^{[15]}$ Specificity can be a useful indicator of the number of unnecessary events (eg. radiographs).

Dwivedi et al. ${ }^{[4]}$ reported $100 \%$ sensitivity and $36.76 \%$ specificity of OAR implementation, signifying that all clinically significant fractures were detected using OAR, and none were missed. Spanos et al. ${ }^{[16]}$ reported $94.12 \%$ sensitivity and $37.65 \%$ specificity when OAR was implemented by a resident orthopedic surgeon. In a study conducted by Yavuz et al., ${ }^{[1]}$ patients were examined by an orthopedic surgeon or orthopedic resident in the ED, and sensitivity and specificity were reported as $94.7 \%$ and $69.6 \%$, respectively.

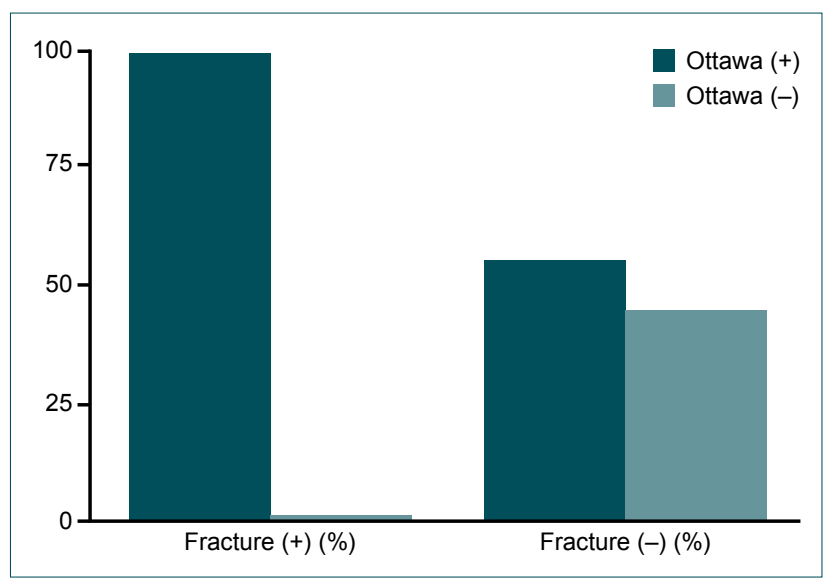

Figure 2. Comparison of patients with and without fracture, in terms of the OAR $(p=0.001)$.
Regarding OAR implementation by general physicians, Can et al. ${ }^{[18]}$ reported $100 \%$ sensitivity and $17 \%$ specificity. In the present study, OAR was also implemented by general practitioners, and $98.39 \%$ sensitivity, $44.61 \%$ specificity was found. Though I case of non-displaced first metatarsal fracture was missed, we believe that OAR is a useful diagnostic tool for the detection of any clinically significant ankle or mid-foot fracture in the ED of a Turkish district hospital. A 30-40\% reduction in the number of unnecessary radiographs following OAR implementation has been reported. It was presently determined that a reduction of $38.02 \%$ was possible, indicating that an approximate third of $x$-rays could be avoided with OAR application in the present ED setting. Reduction in $x-$ rays by even a third can cause significant impact on healthcare cost, in addition to the reduction in radiation hazards.

Certain limitations may have affected the present study. Patients were recruited from the ED of a single hospital. In addition, while all examiners were trained in the application of the OAR, there are unavoidable differences among individuals in palpation technique and assessment of bone tenderness, which may have impacted the present results. Sample size was determined based on previously reported data, and may not have been sufficient for our general population.

In conclusion, the OAR is a highly sensitive method of screening patients with acute ankle and mid-foot injuries. Application of the OAR by well-trained general practitioners may significantly reduce the number of $x$-rays performed, thereby reducing cost of treatment and radiation exposure, in addition to saving time for patients and hospital staff. It is well 
known that physical examination is very important in the detection of occult fracture. Patients with sharp bone tenderness and severe soft tissue swelling but negative radiographic results are considered to have a high likelihood of fracture, based on the OAR. We suggest that in these cases, ankles should be immobilized in casts to prevent potential fracture displacement.

\section{Conflict of interest: None declared.}

\section{REFERENCES}

1. Knudsen R, Vijdea R, Damborg F. Validation of the Ottawa ankle rules in a Danish emergency department. Dan Med Bull 2010;57:A4142.

2. Wang X, Chang SM, Yu GR, Rao ZT. Clinical value of the Ottawa ankle rules for diagnosis of fractures in acute ankle injuries. PLoS One 2013;8:e63228. Crossref

3. Stiell IG, McKnight RD, Greenberg GH, McDowell I, Nair RC, Wells GA, et al. Implementation of the Ottawa ankle rules. JAMA 1994;271:827-32. Crossref

4. Dwivedi R, Ale SB. Evaluation of the accuracy of "Ottawa ankle rules" for predicting fractures in acute ankle and midfoot injuries. J Uni Collage Med Sci 2014;2:1-5. Crossref

5. Stiell IG, Greenberg GH, McKnight RD, Nair RC, McDowell I, Worthington JR. A study to develop clinical decision rules for the use of radiography in acute ankle injuries. Ann Emerg Med 1992;21:384-90.

6. Auleley GR, Ravaud P, Giraudeau B, Kerboull L, Nizard R, Massin P, et al. Implementation of the Ottawa ankle rules in France. A multicenter randomized controlled trial. JAMA 1997;277:1935-9. Crossref

7. Yuen MC, Sim SW, Lam HS, Tung WK. Validation of the Ottawa ankle rules in a Hong Kong ED. Am J Emerg Med 2001;19:429-32. Crossref

8. Stiell IG, Bennett C. Implementation of clinical decision rules in the emergency department. Acad Emerg Med 2007;14:955-9. Crossref

9. Pigman EC, Klug RK, Sanford S, Jolly BT. Evaluation of the Ottawa clinical decision rules for the use of radiography in acute ankle and midfoot injuries in the emergency department: an independent site assessment. Ann Emerg Med 1994;24:41-5. Crossref

10. Bessen T, Clark R, Shakib S, Hughes G. A multifaceted strategy for implementation of the Ottawa ankle rules in two emergency departments. BMJ 2009;339:b3056. Crossref

11. Leddy JJ, Kesari A, Smolinski RJ. Implementation of the Ottawa ankle rule in a university sports medicine center. Med Sci Sports Exerc 2002;34:57-62. Crossref

12. Stiell I, Wells G, Laupacis A, Brison R, Verbeek R, Vandemheen K, et al. Multicentre trial to introduce the Ottawa ankle rules for use of radiography in acute ankle injuries. Multicentre Ankle Rule Study Group. BMJ 1995;311:594-7. Crossref

13. Bachmann LM, Kolb E, Koller MT, Steurer J, ter Riet G. Accuracy of Ottawa ankle rules to exclude fractures of the ankle and mid-foot: systematic review. BMJ 2003;326:417. Crossref

14. Jenkin M, Sitler MR, Kelly JD. Clinical usefulness of the Ottawa Ankle Rules for detecting fractures of the ankle and midfoot. J Athl Train 2010;45:480-2. Crossref

15. Fritz JM, Wainner RS. Examining diagnostic tests: an evidence-based perspective. Phys Ther 2001;81:1546-64.

16. Spanos I, Samdanis V, Chytas A, Beslikas T, Hatzokos I. Implementation of the Ottawa ankle rules by resident orthopaedic surgeons in an emergency department. Clin Res Foot Ankle 2014;2:1000127.

17. Yavuz U, Sokucu S, Demir B, Yalcinkaya M, Cetinkaya E, Coskun M, et al. Evaluation of rutine radiographical necessity according to Ottawa rules in patients with ankle trauma. Goztepe Tip Dergisi 2013;28:204-8.

18. Can U, Ruckert R, Held U, Buchmann P, Platz A, Bachmann LM. Safety and efficiency of the Ottawa Ankle Rule in a Swiss population with ankle sprains. Swiss Med Wkly 2008;138:292-6.

\title{
ORIJINAL ÇALIŞMA - ÖZET
}

\section{Ottawa ayak bileği kurallarının ülkemizde devlet hastanesi acil servisinde görevli pratisyen hekimler tarafinca kullanımı}

\section{Dr. Murat Daş, ${ }^{1}$ Dr. Aytun Temiz, ${ }^{2}$ Dr. Yunsur Çevik ${ }^{3}$}

\author{
${ }^{1}$ Balıkesir Edremit Devlet Hastanesi, Acil Tıp Kliniği, Balıkesir \\ ${ }^{2}$ Edremit Devlet Hastanesi, Ortopedi ve Travmatoloji Kliniği, Balıkesir \\ ${ }^{3}$ Ankara Keçiören Eğitim Araştırma Hastanesi, Acil Tıp Kliniği, Ankara
}

AMAÇ: Ottawa ayak bileği kurallarını ülkemizde devlet hastanesinde görevli pratisyen hekimler tarafınca kullanılmasının etkinliğini araştırmak. GEREÇ VE YÖNTEM: İki yüz yataklı devlet hastanesi ikinci basamak acil servise, ayak-ayakbileği travması ile müracaat eden 405 hasta çalışmaya dahil edildi. Tüm hastalar pratisyen hekim tarafınca muayene edilerek Ottawa pozitif veya negatif olarak sınıflandırıldı. Tüm hastalara ön-arka ve yan, ayak ve ayak bileği grafisi çekildi. Grafiler, hastanın Ottawa grubunu bilmeyen ortopedi ve radyoloji uzmanlarınca değerlendirilerek klinik olarak anlamlı kırık olup olmadığı saptandı. Takiben sonuca göre Ottawa ayakbileği kuralı için duyarııık, özgüllük, pozitif ve negatif kestirim değerleri hesaplandı. BULGULAR: İki yüz elli bir (\%6।.97) hasta Ottawa (+), I54 hasta (\%38.02) Ottawa (-) olarak saptandı. Altmış iki (\%।5.3) hastada klinik olarak anlamlı kırık tespit edildi. Kırık olan 62 hastanın 6 I'inde (\%98.4) Ottawa (+) idi. Deplase olmamış birinci metatars kırığı tespit edilen bir (\%। .6) hastada Ottawa (-) idi. Bununla birlikte kırık saptanmayan 190 (\%55.4) hasta Ottawa (+), I53 (\%44.6) hasta Ottawa (-) idi (p<0.00 I). Duyarlıık, özgüllük, pozitif ve negatif kestirim değerleri sırasıyla \%98.39, \%44.6I, \%24.30 ve \%99.35 idi. Eğri alında kalan alan 0.7 I olarak hesaplandı. Bu sonuçlara göre Ottawa ayakbileği kurallarının olası radyolojik tetkik azaltma oranı \%38.02 olarak tespit edildi.

TARTIŞMA: Ottawa ayak bileği kuralları (OAR) akut ayak bileği ve ayak orta bölüm yaralanmaları geçiren hastalarda yüksek derecede duyarlı tarama testidir. liyi eğitimli pratisyen hekimlerin OAR'yi uygulaması çekilen radyogramların sayısının anlamlı derecede azalmasını sağlayarak, hasta ve personelin zamandan tasarruf sağlamasına ek olarak tedavi maliyetini ve radyasyona maruziyeti de azaltır.

Anahtar sözcükler: Ottawa ayak bileği kuralları; pratisyen hekim. 